\title{
Clinicoepidemiology of Skin Diseases in Children Seen at the University Hospital Center Morafeno, Toamasina, Madagascar
}

\author{
Irina Mamisoa Ranaivo $\mathbb{D D}^{1}{ }^{1}$ Fandresena Arilala Sendrasoa $(\mathbb{D})^{2}$ \\ Malalaniaina Andrianarison, ${ }^{2}$ Moril Sata, ${ }^{1}$ Onivola Raharolahy, ${ }^{2}$ \\ Dimby Stephane Ralandison, ${ }^{3}$ Lala Soavina Ramarozatovo, ${ }^{2}$ \\ and Fahafahantsoa Rapelanoro Rabenja $\mathbb{D}^{2}$ \\ ${ }^{1}$ Departments of Dermatology, University Hospital Morafeno, Toamasina, Madagascar \\ ${ }^{2}$ Department of Dermatology, Joseph Raseta Befelatanana University Hospital, Antananarivo, Madagascar \\ ${ }^{3}$ Department of Rheumatology, University Hospital of Morafeno, Toamasina, Madagascar
}

Correspondence should be addressed to Irina Mamisoa Ranaivo; irinamami@yahoo.fr

Received 11 April 2021; Accepted 31 August 2021; Published 9 September 2021

Academic Editor: Markus Stucker

Copyright ( 2021 Irina Mamisoa Ranaivo et al. This is an open access article distributed under the Creative Commons Attribution License, which permits unrestricted use, distribution, and reproduction in any medium, provided the original work is properly cited.

\begin{abstract}
Introduction. The child's skin diseases are common and very diverse. Many studies concerning pediatric dermatoses have been carried out in Africa and the rest of the world. Few epidemioclinical data reflect these skin diseases in children, especially in the east coast of Madagascar. We aim to describe the pattern skin diseases among children seen at the University Hospital Center Morafeno, Toamasina, Madagascar. Patients and Methods. A retrospective study over a 3-year period from January 2017 to December 2019 was conducted in children seen in the Dermatology Department of University Hospital Center Morafeno, Toamasina, with skin diseases. Results. During the study period, 347 children out of the 1584 new patients were retained with a sex ratio of 0.86 . The mean age was 6.4 years old. The main diseases identified were skin infectious diseases (43, 23\%), allergic dermatoses (24.21\%), and autonomous dermatosis (15.56\%). Conclusion. Our study revealed the importance of infectious and allergic dermatoses in Toamasina. It is necessary to carry out simple preventive actions such as hygiene.
\end{abstract}

\section{Introduction}

The child's skin diseases are common and very diverse. These skin disorders give uneasiness and anxiety of parents. Many studies concerning pediatric dermatoses have been carried out in Africa and the rest of the world [1-4]. Environmental factors play a significant role in skin disease. However, in Madagascar, particularly in Toamasina, this entity remains little studied. Toamasina is a city on the east coast of Madagascar with a hot and humid climate. We aim to describe the pattern skin diseases among children seen at the CHU Morafeno, Toamasina, Madagascar.

\section{Patients and Methods}

This is a retrospective study of all patients aged $\leq 15$ years attending the outpatient dermatology who were examined at the Department of Dermatology at the University Hospital Center Morafeno in Toamasina, Madagascar, during 36 months (from January 2017 to December 2019). Epidemiologic data (age and gender) and diagnosis were collected from the patient's medical records. Patients with missing information were excluded from the study. The diagnoses reported on the medical records were based on clinical features and were confirmed by laboratory tests when indicated. The studied cases were further divided according to 
etiology, into the following groups: infectious skin diseases (bacterial skin infections, parasitic infestations, fungal infections, and viral infections), allergic dermatoses, autonomous dermatosis or inflammatory skin diseases, genodermatosis or congenital dermatosis, skin tumors, dysimmune diseases, and toxidermia (drug reaction). The data collections were carried out by the Excel 2010 software. The statistical analysis was processed on the EPI-INFO software version 7.2.2 16.

\section{Results}

During the study period, a total of 1584 new patients with skin diseases were seen, including 347 pediatric patients. Pediatric consultations represent $21.90 \%$ of all dermatology outpatient. Among the 347 pediatric patients, 159 (46.36\%) were boys and $184(53.64 \%)$ girls. There was a female preponderance (sex ratio: 0.86). Age ranges from newborn to 15 years (mean age 6.4years). The time between the onset of illness and the first consultation varied between one day to120 months with a mean delay of 12.18 months. The main diseases identified were skin infectious disease $(43,23 \%)$, allergic dermatoses $(24,21 \%)$, autonomous dermatosis $(15$, $56 \%)$, genodermatosis or congenital dermatosis $(9,51 \%)$, tumoral dermatosis (2.88\%), dysimmune diseases $(1.44 \%)$, and toxidermia (1.15\%). Table 1 shows the frequency and pattern of skin diseases groups according to the age ranges of the patients.

Among the skin infectious disease, fungal infections were noted in 58 cases $(31.67 \%)$ which consisted of pityriasis versicolor in $12.66 \%$ and tinea corporis in $10 \%$. Regarding bacterial skin diseases, they were noted in 22 cases $(14.67 \%)$ including impetigo (8\%) (Figure 1), and there were 2 cases of skin tuberculosis. Viral infections represented $16.67 \%$ of infectious diseases, including molluscum contagiosum $(10.66 \%)$. As for parasitic infestations, 41 cases were scabies $(27.33 \%)$. Table 2 provides the distribution of children according to infectious diseases.

Allergic dermatoses were mainly represented by atopic dermatitis (72.62\%). Most of the autonomous dermatoses were represented by vitiligo (48.15\%) (Figure 2), followed by acne and psoriasis, respectively, $20 \%$ and $16.67 \%$. Congenital dermatoses and/or genodermatoses mainly consisted of tuberous hemangiomas (42.42\%), nevi (18.18\%), and congenital ichthyosis $(12.12 \%)$. These 3 groups of noninfectious dermatoses are given in Table 3. Skin tumors were mainly benign tumors (10 cases), of which 5 cases were keloids. There were 5 cases of autoimmune diseases including 2 cases of autoimmune bullous dermatosis and 3 cases of scleroderma. Finally, 4 cases of drug eruption were fixed pigmented erythema.

\section{Discussion}

The aim of this study was to describe the pattern skin diseases among children $\leq 15$ years seen in Dermatological Outpatient Department at the University Hospital Center
Morafeno, Toamasina. This study provided an overview of children's skin diseases in Toamasina. The present study found that $21.90 \%$ of the patients seen in dermatology in Toamasina were children; this frequency is comparable to the results of the literature $[1,2,5]$. The demographic profile of these children was superimposed on that of the literature. There was a predominance of the female gender in our study with 53.64\%. Similar results were found in Côte d'Ivoire with a female predominance at 54.06\% [3] and in Greece at 52.8\% [6]. In Mali and India, it found a male predominance with, respectively, $55.10 \%$ and $58 \%[1,4]$.

The average duration of disease progression before consultation is quite long, around 12.18 months. This could be explained by the recent opening of the Dermatology Department at the University Hospital Center Morafeno, Toamasina (2016). Poor economic and geographic accessibility to healthcare services by patients, recourse to traditional treatments, or self-medication delayed specialist consultations [7].

Infectious dermatoses was the largest group of skin disorders in childhood in our study constituting $43.23 \%$ of total 347 cases, followed by allergic dermatoses (24.21\%) and autonomous dermatoses (15.56\%). As in other African studies, infectious skin diseases were frequent and affected different age groups of children $[1,8]$. The infectious diseases observed were fungal, parasitic, viral, and bacterial dermatoses. But the most common were superficial skin fungal infections (tinea corporis and pityriasis versicolor) and parasitic dermatoses in particular scabies. This frequency could be the consequence of poor hygiene and limited socioeconomic condition. The hot and humid climate also favours the appearance of infectious dermatoses [9].

After infectious dermatoses, there were allergic dermatoses, mainly atopic dermatitis as in most studies both in Africa and in Europe $[1,2]$. These dermatoses affected all age groups. Lifestyle factors linked to urbanization were associated with an increased risk of allergic diseases in Africa $[10,11]$.

Concerning autonomous dermatoses, the most common were vitiligo, acne, and psoriasis. These dermatoses mainly affected the 11-15 age group. Although benign, they could have a negative impact on the quality of life of children, adolescents, and their families [12]. This high frequency for this age group is thought to be due to the aesthetic discomfort leading to a consultation. Vitiligo can appear soon after birth until late adulthood. But it appears before the age of 12 in $32-40 \%$ of cases [13]. And acne is often associated with adolescence but can appear at any age, especially in the prepubertal period [14].

Skin tumors were benign and appeared mostly in the 11-15-year age group. In fact, skin cancers are rare in children except in the case of preexisting dermatoses such as albino or xeroderma pigmentosum. These skin tumors were essentially keloids. The absence of comorbidities promotes good wound healing in children compared to adults due to good vascularisation of the skin. But hypertrophic and keloid scars are frequent in the prepubertal 
TABLE 1: The frequency and pattern of skin diseases groups according to the age ranges of the patients

\begin{tabular}{|c|c|c|c|c|c|c|}
\hline \multirow{2}{*}{ Skin diseases } & \multicolumn{6}{|c|}{ Age ranges } \\
\hline & $<1$ year & $1-5$ years & $6-10$ years & $11-15$ years & Total & Percentage (\%) \\
\hline Infectious dermatoses & 22 & 62 & 44 & 22 & 150 & 43.23 \\
\hline Autonomous dermatoses & 01 & 15 & 14 & 24 & 54 & 15.56 \\
\hline Allergic dermatoses & 11 & 30 & 25 & 18 & 84 & 24.21 \\
\hline Congenital dermatoses & 15 & 08 & 06 & 04 & 33 & 9.51 \\
\hline Dysimmune dermatoses & 0 & 0 & 02 & 03 & 05 & 1.44 \\
\hline Tumors skin & 0 & 02 & 01 & 07 & 10 & 2.88 \\
\hline Toxidermia & 0 & 03 & 01 & 0 & 04 & 1.15 \\
\hline Others & 05 & 02 & 0 & 0 & 07 & 2.02 \\
\hline Total & 54 & 122 & 93 & 78 & 347 & 100 \\
\hline
\end{tabular}

TABLE 2: The distribution of children according to infectious diseases.

\begin{tabular}{|c|c|c|c|}
\hline Dermatoses & Diagnosis & Number of patients (150) & Percentage (\%) \\
\hline \multirow{5}{*}{ Fungal infectious } & Pityriasis versicolor & 19 & 12.66 \\
\hline & Tinea corporis & 15 & 10.00 \\
\hline & Tinea capitis & 14 & 9.33 \\
\hline & Seborrheic dermatitis & 10 & 6.66 \\
\hline & Total & 58 & 38.67 \\
\hline \multirow{3}{*}{ Parasitic infestation } & Scabies & 41 & 27.33 \\
\hline & Cutaneous larva migrans & 04 & 02.66 \\
\hline & Total & 45 & 30 \\
\hline \multirow{7}{*}{ Viral infections } & Molluscum contagiosum & 16 & 10.66 \\
\hline & Gibert's pityriasis rosea & 03 & 2.00 \\
\hline & Varicella & 01 & 0.66 \\
\hline & Zona & 02 & 1.33 \\
\hline & Herpes & 01 & 0.66 \\
\hline & Warts & 02 & 1.33 \\
\hline & Total & 25 & 16.67 \\
\hline \multirow{5}{*}{ Bacterial skin diseases } & Impetigo & 12 & 08.00 \\
\hline & Furunculosis & 07 & 0.46 \\
\hline & Abcess & 01 & 0.66 \\
\hline & Cutaneous tuberculosis & 02 & 1.33 \\
\hline & Total & 22 & 14.67 \\
\hline
\end{tabular}

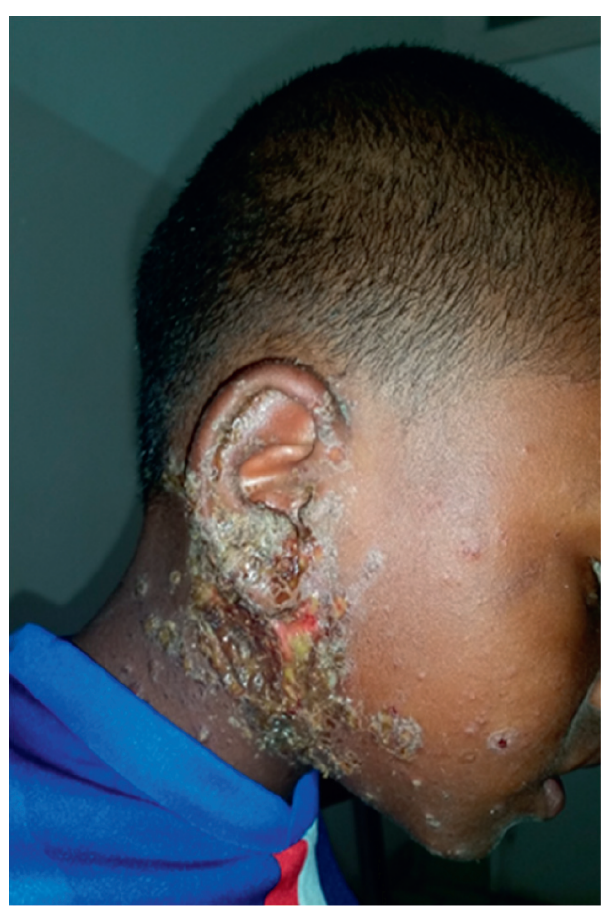

Figure 1: Impetigo. 


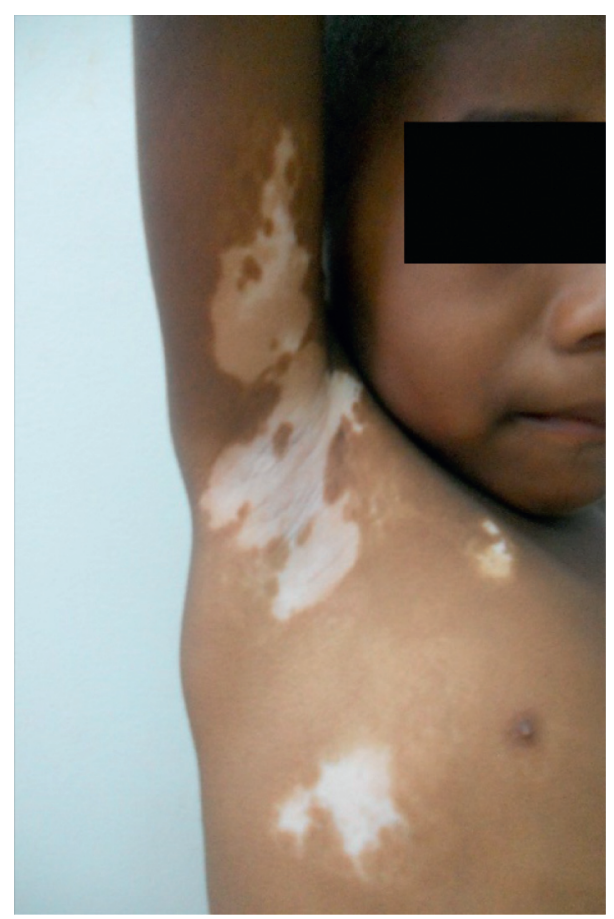

FIgURE 2: Vitiligo.

TABLE 3: The distribution of children according to noninfectious skin diseases.

\begin{tabular}{|c|c|c|c|}
\hline Dermatoses & Diagnostics & Number of patients & Percentage (\%) \\
\hline \multirow{5}{*}{ Allergic dermatosis } & Atopic dermatitis & 61 & 72.62 \\
\hline & Contact eczema & 10 & 11.90 \\
\hline & Prurigo & 12 & 14.29 \\
\hline & Urticaria & 01 & 1.19 \\
\hline & Total & 84 & 100 \\
\hline \multirow{6}{*}{ Autonomous dermatoses } & Vitiligo & 26 & 48.14 \\
\hline & Acne & 11 & 20.37 \\
\hline & Psoriasis & 09 & 16.67 \\
\hline & Lichen striatus & 06 & 11.11 \\
\hline & Alopecia areata & 02 & 3.07 \\
\hline & Total & 54 & 100 \\
\hline \multirow{10}{*}{ Congenital dermatoses } & Hemangioma & 14 & 42.42 \\
\hline & Nevi & 06 & 18.18 \\
\hline & Congenital ichthyosis & 04 & 12.12 \\
\hline & Pityriasis rubra pilaris & 03 & 09.09 \\
\hline & Neurofibromatosis & 02 & 06.06 \\
\hline & Klippel-Trenaunay & 01 & 03.03 \\
\hline & Bourneville tuberous sclerosis & 01 & 03.03 \\
\hline & Anhidrotic ectodermal dysplasia & 01 & 03.03 \\
\hline & Aplasia cutis congenita & 01 & 03.03 \\
\hline & Total & 33 & 100 \\
\hline
\end{tabular}


TABle 4: Comparative analysis of some studies of skin diseases in children reported in the literature.

\begin{tabular}{|c|c|c|c|c|}
\hline Study & Country & Period study & $\begin{array}{c}\text { Number of } \\
\text { patients }\end{array}$ & Most frequent skin diseases \\
\hline $\begin{array}{l}\text { Ben Saif and Al Shehab } \\
\text { [17] }\end{array}$ & $\begin{array}{l}\text { Al-Khabar } \\
\text { Saudi Arabia }\end{array}$ & $\begin{array}{c}\text { January } 2004 \text { to January } \\
2006\end{array}$ & 383 & $\begin{array}{c}\text { Dermatitis and eczema } 30.30 \% \\
\text { Infectious diseases } 12.5 \% \\
\text { Pigmentary disorders } 8.9 \% \\
\end{array}$ \\
\hline Sacchidanand et al. [9] & $\begin{array}{l}\text { Bangalore } \\
\text { India }\end{array}$ & January 2011 to June 2011 & 1090 & $\begin{array}{c}\text { Infectious diseases } 32.4 \% \\
\text { Eczema } 20.66 \% \\
\text { Pigmentary disorders } 7.4 \%\end{array}$ \\
\hline Vakirlis et al. [6] & $\begin{array}{c}\text { Thessaloniki } \\
\text { Greece }\end{array}$ & $\begin{array}{l}\text { January } 2013 \text { to December } \\
2015\end{array}$ & 940 & $\begin{array}{c}\text { Dermatitis/eczema } 31.4 \% \\
\text { Viral infection } 12.5 \% \\
\text { Pigmentary disorders } 7.3 \%\end{array}$ \\
\hline Özçelik et al. [18] & $\begin{array}{c}\text { Erzincan } \\
\text { Turkey }\end{array}$ & $\begin{array}{l}\text { January } 2014 \text { to November } \\
2016\end{array}$ & 10115 & $\begin{array}{c}\text { Infectious diseases } 24.62 \% \\
\text { Eczema } 21.95 \% \\
\text { Acne and follicular diseases } 18.45 \% \\
\end{array}$ \\
\hline Kourouma et al. [3] & $\begin{array}{l}\text { Treichville } \\
\text { Abidjan }\end{array}$ & $\begin{array}{l}\text { January } 2010 \text { to December } \\
2014\end{array}$ & 3587 & $\begin{array}{c}\text { Infectious diseases } 29.2 \% \\
\text { Immunoallergic dermatitis } 29.1 \% \\
\text { Inflammatory dermatoses } 26.67 \%\end{array}$ \\
\hline Kiprono et al. [19] & Tanzania & $\begin{array}{l}\text { September } 2012 \text { to August } \\
2013\end{array}$ & 340 & $\begin{array}{c}\text { Infectious diseases } 43.5 \% \\
\text { Eczema dermatitis } 28.5 \% \\
\text { Pigmentary disorders } 7.4 \% \\
\end{array}$ \\
\hline Miotto et al. [20] & $\begin{array}{c}\text { Sao Paolo } \\
\text { Brazil }\end{array}$ & $\begin{array}{c}\text { January } 2017 \text { to December } \\
2017\end{array}$ & 2330 & $\begin{array}{c}\text { Atopic dermatitis } 18.3 \% \\
\text { Genodermatoses } 14.2 \% \\
\text { Infectious diseases } 12.6 \%\end{array}$ \\
\hline Present survey & $\begin{array}{l}\text { Toamasina } \\
\text { Madagascar }\end{array}$ & $\begin{array}{c}\text { January } 2017 \text { to December } \\
2019\end{array}$ & 347 & $\begin{array}{c}\text { Infectious diseases } 43.23 \% \\
\text { Allergic dermatoses } 24.21 \% \\
\text { Autonomous or inflammatory dermatoses } \\
15.56 \%\end{array}$ \\
\hline
\end{tabular}

period as part of the hormonal peak [15, 16]. Table 4 provides some studies of skin diseases in children reported in the literature.

\section{Conclusion}

Childhood skin diseases are variable and frequent in dermatological outpatient. The epidemioclinical characteristics of dermatoses in children in Toamasina did not differ from skin disorders in children seen in Africa. Our study revealed the importance of dermatological conditions, in particular infectious and allergic, as well as autonomous dermatoses. It is necessary to carry out simple preventive actions such as hygiene to encourage and educate patients to come to the hospital in time for appropriate treatment.

\section{Data Availability}

The data used to support the findings of this study are included within the article.

\section{Conflicts of Interest}

The authors declare that they have no conflicts of interest.

\section{References}

[1] Y. Fofana, B. Traore, A. Dicko, O. Faye, S. Berthe, and L. Cisse, "Profil épidémio-clinique des dermatoses chez les enfants vus en consultation dermatologique dans le service de dermatologie du centre national d'appui à la lutte contre la maladie à
Bamako (Mali)," Pan African Medical Journal, vol. 25, p. 238, 2016.

[2] A. Arsouze, C. Fitoussi, P.-P. Cabotin et al., "Motifs de consultation en dermatologie des sujets de peau noire d'origine africaine et antillaise: enquête multicentrique en région parisienne," Annales de Dermatologie et de Vénéréologie, vol. 135, no. 3, pp. 177-182, 2008.

[3] H. S. Kourouma, Y. I. Kouassi, E. J. Ecra, M. Kaloga, I. P. Gbery, and C. Ahogo, "Dermatoses de l'enfant: panorama des entités cliniques en consultation à Abidjan," Revue International des Sciences Médicales, vol. 19, no. 2, pp. 144-148, 2017.

[4] J. Bist, S. Rana, N. Kumari, R. Singh, and A. Mehta, "Prevalence of skin diseases among infants in a tertiary medical facility in Uttarakhand," International Journal of Research in Medical Sciences, vol. 3, no. 5, pp. 1172-1176, 2015.

[5] N. C. Dlova, A. Chateau, N. Khoza et al., "Prevalence of skin diseases treated at public referral hospitals in KwaZulu-Natal, South Africa," British Journal of Dermatology, vol. 178, p. e1, 2018.

[6] E. Vakirlis, G. Theodosiou, Z. Apalla, M. Arabatzis, E. Lazaridou, and E. Sotiriou, "A retrospective epidemiological study of skin diseases among pediatric population attending a tertiary Dermatology Referral Center in Northern Greece," Clinical, Cosmetic and Investigational Dermatology, vol. 10, pp. 99-104, 2017.

[7] I. M. Ranaivo, F. A. Sendrasoa, M. O. J. Harioly Nirina, N. Rasamoelina, O. Raharolahy, and H. S. Razakanary, "Selfmedication during dermatological disorders seen in the dermatology department of the university hospital joseph raseta befelatanana, antananarivo Madagascar," EC Microbiology, vol. 15, no. 5, pp. 339-343, 2019. 
[8] R. R. Yotsu, K. Kouadio, B. Vagamon et al., "Skin disease prevalence study in schoolchildren in rural Côte d'Ivoire: implications for integration of neglected skin diseases (skin NTDs)," PLoS Neglected Tropical Diseases, vol. 12, no. 5, Article ID e0006489, 2018.

[9] S Sacchidanand, M. S. Sahana, G. S. Asha, and K. Shilpa, "Pattern of pediatric dermatoses at a referral centre," Indian Journal of Pediatrics, vol. 81, no. 4, pp. 375-380, 2014.

[10] F. A. Sendrasoa, I. M. Ranaivo, and N. H. Razanakoto, "Epidemiology and associated factors of atopic dermatitis in Malagasy children," Allergy Asthma Clin Immunol, vol. 6, no. 16, p. 4, 2020.

[11] I. Khalfallah, S. Louhaichi, B. Hamdi, and A. Hamzaoui, "Les allergies de l'enfant en Afrique," Revue Française d'Allergologie, vol. 60, no. 4, pp. 195-196, 2020.

[12] A. Salman, A. D. Yucelten, E. Sarac, M. H. Saricam, and N. Perdahli-Fis, "Impact of psoriasis in the quality of life of children, adolescents and their families: a cross-sectional study," Anais Brasileiros de Dermatologia, vol. 93, no. 6, pp. 819-823, 2018.

[13] E. Nicolaidou, S. Mastraftsi, V. Tzanetakou, and D. Rigopoulos, "Childhood vitiligo," American Journal of Clinical Dermatology, vol. 20, no. 4, pp. 515-526, 2019.

[14] M. Napolitano, G. Ruggiero, G. Monfrecola, M. Megna, and M. Megna, "Acne prevalence in 9 to 14 -year-old old patients attending pediatric ambulatory clinics in Italy," International Journal of Dermatology, vol. 57, no. 11, pp. 1320-1323, 2018.

[15] J. Sanchez, F. Antonicelli, D. Tuton, S. Mazouz Dorval, and C. François, "Particularités de la cicatrisation de l'enfant," Annales de chirurgie plastique esthétique, vol. 61, p. 341-347, 2016.

[16] N. Dégardin, C. Jaloux, S. Mallet, S. Hesse, and J. Bardot, "Les tumeurs cutanées de l'enfant," Annales de Chirurgie Plastique Esthétique, vol. 61, no. 5, pp. 498-512, 2016.

[17] G. A. Ben Saif and S. A. Al Shehab, "Pattern of childhood dermatoses at a teaching hospital of Saudi Arabia," International Journal of Health Sciences, vol. 2, no. 2, pp. 63-74, 2008.

[18] S. Özcelik, I. Kulaç, I. Kulac, M. Yazici, and E. Ocal, "Distribution of childhood skin diseases according to age and gender, a single institution experience," Türk Pediatri Arşivi, vol. 53, no. 2, pp. 105-112, 2018.

[19] S. K. Kiprono, J. W. Muchunu, and J. E. Masenga, "Skin diseases in pediatric patients attending a tertiary dermatology hospital in Northern Tanzania: a cross-sectional study," BMC Dermatology, vol. 15, no. 1, p. 16, 2015.

[20] I. Z. Miotto, V. R. Bessa, L. B. d. A. Vasconcelos, L. P. Samorano, M. C. Rivitti-Machado, and Z. N. P. d. Oliveira, "Pediatric dermatoses pattern at a Brazilian reference center," Jornal de Pediatria, vol. 97, no. 2, pp. 211-218, 2021. 